\title{
Latar Kepercayaan Yang Mempengaruhi Permukiman Dan Rumah Tengger Di Jawa Timur
}

\section{Hari Lelono}

Keywords: settlement, traditional, pattern, beliefs, hinterland, etnography, ethnoarchaeology

\section{How to Cite:}

Lelono, H. (2002). Latar Kepercayaan Yang Mempengaruhi Permukiman Dan Rumah Tengger Di Jawa Timur. Berkala Arkeologi, 22(1), 49-57. https://doi.org/10.30883/jba.v22i1.849

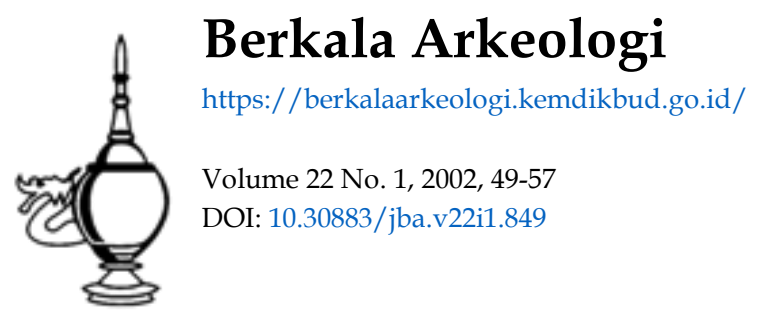

\section{cc) (i) (5)}

This work is licensed under a Creative Commons Attribution-NonCommercial-ShareAlike 4.0 International License. 


\title{
LATAR KEPERCAYAAN YANG MEMPENGARUHI PERMUKIMAN DAN RUMAH TENGGER DI JAWA TIMUR
}

\author{
TM Hari Lelono \\ (Balai Arkeologi Yogyakarta)
}

\section{Pendahuluan}

Permukiman merupakan lingkungan tempat manusia hidup dan melakukan berbagai macam aktivitas, oleh karena itu permukiman dapat diartikan sebagai suatu tempat (ruang) tempat sekelompok penduduk berkumpul dan hidup bersama untuk melakukan aktivitas rutinitasnya. Dalam konteks tersebut, mereka harus mempertahankan kelangsungan permukimannya untuk mengembangkan segala aspek kehidupan bagi individu-individu dan warga masyarakat secara harmonis. Syarat utama permukiman adalah adanya lahan yang tersedia, dalam hal ini lahan dapat berupa lahan datar di daerah tepi pantai delta-delta sungai, daerah antara dataran dan pegunungan serta lahan yang terletak dilereng-lereng pegunungan. Dalam lahan lereng pegunungan tentunya para pemukim tersebut mempunyai alasan sendiri untuk memilih lokasi tersebut. Beberapa alasan mungkin disebabkan oleh faktor sosial/ politis dan ekonomi, faktor religius, dan atau gabungan dari beberapa faktor tersebut di depan, sesuai dengan tujuan dan kebutuhan kelangsungan hidup.

D. van der Zee (1979) mengemukakan bahwa permukiman adalah (1) Proses dengan jalan mana orang-orang menetap pada suatu wilayah, dan (2) Akibat dari proses ini. Menurut Vernor C Finch (1957), isitilah permukiman di dalam hal ini adalah kata benda yang meliputi karakteristik kelompok-kelompok manusia berdasarkan unit-unit kediaman, termasuk fasilitas-fasilitasnya seperti rumah-rumah, serta jalan-jalan yang melayani penduduk setempat. Salah Satu komponen yang sangat penting dalam konteks permukiman dan rumah tradisional adalah, adanya latar religi/ kepercayaan yang dapat menjadi ciri khasnya. Sebagaimana kita ketahui bersama, bahwa masyarakat tradisional masih kuat mempertahankan konsep-konsep religi yang mereka anut sampai kini, berupa kepercayaan terhadap kekuatan gaib yang diwujudkan dalam bentuk tempat-tempat tertentu, seperti misalnya gunung atau ketinggian, air, pohonpohon/ batu besar. Semua hal tersebut merupakan wujud atau simbol-simbol dariadanya kepercayaan berupa pemujaan kepada roho-roh leluhur. Penjelasan di depan tersebut memperjelas batasan dan pengertian serta syarat-syarat sebuah permukiman. Sebagaimana telah kita ketahui jenis dan bentuk permukiman sekurangnya dapat dibedakan menjadi tiga jenis, antara lain: (1) Permukiman daerah pantai, (2) Permukiman dataran rendah dan (3) Permukiman di daerah dataran tinggi/ pegunungan. Ketiga permukiman ini mempunyai latar karakteristik yang berbeda dan bahkan peralatan yang digunakan pun terdapat perbedaan, hal tersebut karena 
menyangkut bentuk lingkungan alam yang berbeda serta akan menghasilkan pola konsumsi dan tata cara pengolahan lahan pertanian/perladangan yang berbeda sesuai dengan bentuk geografis setempat. Selain itu, bentuk-bentuk rumah tinggal dan permukiman pun juga mengalami perubahan pada materi yang digunakan serta pemba-gian dan fungsi tata ruangnya. Dalam hal ini unsur kepercayaan dan adat-istiadat menjadi tolok ukur dalam konsep-konsep untuk pembangunan permukiman seutuhnya.

Paper ini mencoba mengungkap sebuah permukiman dan rumah suatu kelompok masyarakat yang tinggal di dataran tinggi/pegunungan yang di kenal dengan Suku Tengger yang hidup di daerah Gunung Bromo, GunungTengger dan Gunung Semeru. Selama ini studi tentang bentuk-bentuk permukiman tradisional sudah sering dilakukan oleh para peneliti, seperti desa-desa tradisional di Bali, Sunda, Kalimantan dan lainlain. Namun bentuk permukiman Tengger merupakan salah satu yang unik dan masih belum banyak dilakukan pengkajian. Pada Suku Tengger bentuk tata ruang permukimannya masih mempertahankan pola-pola lama, yakni masih terdapatnya tinggalantinggalan nenek moyang masih dihormati dan di sikapi sebagai warisan atau tradisi. Tentunya tradisi yang dimaksud mengandung nilai-nilai positif menyangkut pandangan hidup masyarakatnya, serta nilai-nilai positif yang berkaitan dengan estetika, ekosistem untuk mempertahankan kelestarian alam dan lingkungan budaya Tengger.

\section{Tengger dan Lingkungannya}

Suku Tengger hidup di daerah pegunungan yang meliputi empat Kabupaten, diantaranya: Kabupaten Pasuruan, Kabupaten Probolinggo, Kabupaten Lumajang dan Kabupaten Malang. Secara geografis dataran tinggi Tengger merupakan kaldera yang luas dengan aneka ragam flora dan fauna yang hidup di lahan seluas kurang lebih 600 kilometer persegi dengan udara dingin. Terletak pada ketinggian 2060 dari muka laut (dpl). Kondisi desa-desa sekitarnya berlereng-tereng yang digunakan oleh penduduk untuk mengolah lahan pertanian pada kemiringan sampai $60^{\circ}$. Daerah ini merupakan luapan lahar Gunung Bromo yang secara periodik mengeluarkan letusan, humus di wilayah ini tebal dan vulkanis, yang menjadikannya salah satu yang paling subur di Jawa (Donner, 1987). Iklim yang sangat dingin menjadikannya cocok untuk tanaman sayur mayur, seperti bawang merah, kobis, wortel, dan kentang. Secara tradisional menjadikannya makanan pokok bagi penduduk desa setempat. Suatu fenomena budaya yang menarik pada suku Tengger, adalah tradisi masyarakatnya. Unik dan menariknya tradisi tersebut telah mengundang berbagai ilmuwan/ peneliti, utamanya pada aspek antropologis dan sosiologis untuk melakukan kajian-kajian. selain alam dan panorama yang indah, suku ini juga memiliki beberapa upacara tradisional yang sangat terkenal seperti misalnya upacara kasoda, upacara karo yang secara rutin dilakukan oleh masyarakatnya. Salah satu prosesi upacara adat tersebut dilakukan di Gunung Bromo dengan melakukan persembahan ke dalam kawah gunung tersebut, 
yang oleh masyarakat sekitar sering dikaitkan dengan tokoh dan legenda tentang Loro Anteng (Teng) dan Joko Seger (Ger) yang lama kelamaan kedua kata ini lebih mudah untuk diucapkan dan diingat dengan sebutan Tengger.

Aktivitas Gunung Bromo dan Semeru sangat mempengaruhi topografi kawasan ini. Dinding kaldera yang mengelilingi 'laut pasir' sangat terjal, dengan kemiringan sekitar $60^{\circ}$-- $80^{\circ}$ dan ketinggian antara 200 -- $600 \mathrm{~m}$. Uniknya, disekitar kaldera Tengger yang mempesona ini terdapat gunung-gunung yang memiliki hubungan spiritual dengan orang Tengger karena gunung-gunung tersebut dianggap sebagai tempat tinggal roh-roh putera Rara Anteng dan Jaka Seger, dua tokoh legendaris yang dimuliakan orang Tengger. Gunung-gunung yang berdekatan tersebut adalah Gunung Lingker (2278 M), Gunung Pudak Lembu (2636 m), Gunung Jantur (2705 m), Gunung Ider-ider (2617 m), Gunung Pananjakan (2705 m), dan Gunung Mungal (Sutarto, 2001).

Masyarakat Tengger yang hidup di daerah pegunungan menyebut dirinya wong Gunung yang tinggal di atas (gunung) serta masih taat kepada adat-istiadat dan kepercayaan asli. Sedangkan mereka yang tinggal di bawah, pada dataran rendah disebut dengan wong ngare. Kelompok ini mengenal perbedaan sosial seperti kayamiskin, pejabat-abdi, dan dalam kehidupan sehari-hari cenderung individualis. Mereka yang tinggal di Gunung secara adat dan tradisi serta pergaulan sehari-hari tidak mengenal perbedaan, bagi mereka semua orang adalah sama (padha) antara satu individu dengan individu yang lain tidak ada perbedaan. Hal tersebut karena mereka menganggap orang Tengger yang bermukim di dataran rendah maupun pegunungan masih saudara atau satu keturunan (sakturunan) Jaka Seger dan Loro Anteng.

\section{Unsur-Unsur Kekunaan Tengger}

Masyarakat Tengger Pegunungan yang sering pula disebut dengan istilah wong gunung, apabila kita lihat latar tradisinya kemungkinan besar banyak unsur-unsur kekunaan yang masih dapat diungkap. Salah satunya adalah tentang keberadaan masyarakat Tengger. Menurut Pigeaud (1962), menyebutkan bahwa pada tahun 1880 seorang perempuan Tengger menemukan sebuah prasasti yang terbuat dari kuningan di daerah Pananjakan yang termasuk Desa Womokitri, Kabupaten Pasuruan. Prasasti ini bernagka tahun 1327 Saka atau 1407 M. Penemuan ini menguak misteri tentang latar belakang historis orang Tengger. Prasasti tersebut menyebutkan bahwa sebuah desa bernama Walandhit dihuni oleh hulun hyang atau abdi dewata, dan tanah di sekitar Walandhit disebut hila-hila atau suci. Warga Walandhit dibebaskan dari kewajiban membayar titileman, yakni pajak upacara kenegaraan karena mereka berkewajiban melakukan pemujaan terhadap Gunung Bromo, sebuah gunung suci atau 
gunung yang dikeramatkan. Prasasti tersebut dihadiahkan oleh Batara Hyang Wekas ing Sukha (Hayam Wuruk) pada bulan Asada (Sutarto, 2001).

Sementara itu Supomo (1977) dalam disertasinya berpendapat, bahwa dalam sejarah perkembangan kerajaan Majapahit terdapat tiga pejabat tinggi negara yang masingmasing mengurus agama yang dibedakan, yaitu dharmmadhyaksa ring kasawiwan untuk agama Hindu-Siwa, dharmmadhyaksa ring kasogatan untuk agama Budha, serta mantri her haji untuk mengurus 'agama' karesyan. Yang disebut terakhir itu merupakan salah satu pokok bahasan utama yang menyimpulkan bahwa di Jawa terdapat agama para resi, yaitu agamawan yang mengasuh perguruan didaerah-daerah pegunungan, dan yang memuja kepada Yang Tertinggi yang dicitrakan sebagai 'raja gunung', yang disebut sebagai Parwatarajadewa (Sedyawati, 1996).

Unsur-unsur kekunaan Tengger tidak saja dilihat dari prasasti kuningan yang ditemukan, tetapi dapat dilihat pada komponen yang ada di sesa-desa Tengger itu sendiri pada saat ini, yakni dalam tata ruangnya terdapat tempat-tempat yang dikeramatkan dinamakan punden. Punden dapat berupa batu-batu alam yang didirikan tegak, pohon-pohon besar, dan sumber air. Batu tegak/menhir tersebut menyiratkan pada kita, bahwa unsur-unsur dan tradisi megalitik (prasejarah) pada masyarakat ini masih sangat kuat. Tempat para punden dianggap sebagai tempat para roh leluhur yang ditakuti dan dengan perlakuan yang baik, diharapkan dapat memberikan pengayoman bagi seluruh warga masyarakat. Keberadaan batu menhir dengan tradisi yang masih hidup tersebut merupakan salah satu bukti bahwa sebelum masuknya pengaruh agama Hindu dan Budha di Kerajaan Majapahit masyarakat ini telah mengenal suatu kepercayaan yang disebut unsur Indonesia asli atau asli Tengger.

\section{Unsur-Unsur Religius Dalam Permukiman dan Rumah}

'Unsur-unsur kepercayaan asli' Tengger, merupakan pedoman hidup dan juga diaplikasikan dalam bentuk-bentuk bangunan rumah tinggal, serangkaian upacara adat yang secara rutin dilakukan setahun sekali. Selain bangunan rumah tinggal tersebut tentunya dalam pembentukan tata ruang sebuah permukiman mereka juga mengacu pada unsur-unsur kepercayaan dan tradisi nenek moyangnya yakni yang disebut asli Tengger. Unsur pokok dalam kepercayaan mereka adalah adanya suatu kekuatan maha dasyat yang tinggal di gunung, dalam hal ini apa yang disebut pemujaan kepada Parwatarajadewa (yang tertinggi) yakni gunung. Oleh karena itu dalam setiap permukiman desa selalu terdapat tempat-tempat yang dikeramatkan yang disebut dengan punden atau dahyang. Tempat-tempat yang dipilih ada yang terletak diluar permukiman desa, tetapi adapula yang terdapat di tengah-tengah desa biasa disebut dengan dahyang prapatan. Letak punden/dahyang desa, banyu di desa Ngadas terletak di luar permukiman yang dibatasi oleh jalan desa dan areal pertanian. 
Alam vulkanik dengan tanah yang subur menjadikan ciri khas daerah dataran Tengger, merupakan fenomena yang penuh dengan pemandangan dengan tebing-tebing yang curam dan hanya sedikit daerah yang datar/landai. Kondisi alam demikian itu dimanfaatkan oleh orang Tengger sebagai tempat permukiman yang alami dan ideal, selain juga sebagai tempat untuk berladang/bertani dan untuk melakukan aktivitas sehari-harinya, seperti bertanam sayuran, beternak, melakukan pertemuan dengan sesama warga dan berdagang (profan). Sedang pada waktu yang telah ditentukan mereka melakukan upacara adat (sakral) kasoda, karo, entas-entas, dan lain-lain yang dikaitkan dengan legenda Raden Kusuma, bungsu dari 25 bersaudara anak dari Rara Anteng dan Jaka Seger. Upacara kasodo dilakukan di kawah Gunung Bromo sebagai persembahan kepada Raden Kusuma yang telah mengorbankan dirinya untuk kesejahteraan dan keselamatan saudara-saudaranya serta seluruh masyarakat Tengger. Hampir disetiap puncak-puncak gunung besar yang ada disekitarnya juga merupakan tempat bersemayam para leluhur yang dinamakan dahyang atau punden. Letak Gunung Bromo Tengger dan Semeru tempat para leluhur, merupakan salah satu dasar dalam orientasi kosmis penataan tata ruang permukiman dan rumah tradisional masyarakat Tengger.

\section{a. Permukiman}

Sebagai masyarakat yang hidup di daerah pegunungan yang berlereng terjal dan masih mempertahankan tradisi asli nenek moyangnya, tentunya mereka juga memiliki permukiman sebagai tempat untuk berkumpul dan melakukan aktivitas sehari-hari dengan sesama komunitasnya. Permukiman-permukiman itulah yang disebut dengan desa atau dusun sesuai dengan hirarkis pemerintahan desa pada saat ini. Antara desa dengan dusun perbedaannya terletak pada luas wilayah atau populasi penduduknya. Desa membawahi beberapa pedusunan, sedangkan dusun adalah bagian terkecil dari sebuah desa, dusun tidak selalu harus terpisah lokasinya dengan desa, bahkan kadang menjadi satu. Seperti desa atau dusun-dusun pada umumnya, desa di Tengger secara fisik tidak jauh berbeda dengan desa-desa Jawa lainnya. Pola desa Tengger dapat dikatakan mengelompok, yakni mereka membuat rumah selalu berdekatan satu dengan lainnya yang kadang mengikuti jalan desa dan ada yang tidak serta bersusun karena lahan yang berteras. Rumah-rumah tersebut dihubungkan oleh jalan desa dan jalan dusun (gang) sebagai sarana untuk melakukan kegiatan ke antar desa, dusun dan tetangga. Suatu hal yang sangat menarik untuk diamati secara seksama desa-desa tersebut memiliki ciri khas. Kekhasan tersebut lebih disebabkan oleh pengaruh dari sistem kepercayaan yang ada, yakni dengan menempatkan bangunan-bangunan sakral baik yang sudah ada secara alami maupun oleh buatan manusia yang dinamakan punden atau tempat para nenek moyang yang masih dihormati sebagai cikal bakal (pendiri) desa. Letak para punden tersebut dapat terjadi oleh benda-benda alam maupun buatan manusia, wujud punden berupa tempat air (mata air), pohon-pohon besar dan batu alam yang diletakkan dengan cara didirikan. Bentuk punden yang letaknya 
dipinggir desa biasanya berbentuk suatu lahan yang ditumbuhi oleh banyak pohon-pohon besar dengan bebepa sekat/teras untuk pembatas dari susunan batu atau tanaman. Pada bagian paling tinggi atau dalam dari lahan tersebut diletakkan sebuah batu alam yang didirikan dengan tegak (menhir). Kadang-kadang menhir-menhir tersebut diatapi dengan sebuah bangunan kecil tertutup dengan atap seng atau genteng (cungkup).

Dalam satu permukiman atau desa bisa terdapat empat atau lebih tempat-tempat yang diperuntukkan untuk para punden, seperti misalnya punden desa, punden banyu, punden prapatan, punden peteng, dan lain-lain. Dari sekian banyak punden yang cukup penting adalah punden desa. Penting disini karena dianggap sebagai leluhur dan cikal bakal dari seluruh penduduk setempat. Oleh karena itu, sebuah permukiman dari segi pembagian tata ruangnya dapat dibedakan menjadi beberapa lahan seperti:

1. Lahan untuk meletakkan tempat sarana umum, sekolahan, balai desa, dan rumahrumah penduduk.

2. Lahan atau tempat-tempat para punden diletakkan, misalnya di tengah desa, pojok desa, atau di tempat-tempat sumber air dan tinggi.

3. Lahan pertanian, untuk menanam sayur-mayur (wortel, kubis, kentang, jagung, dan lain-lain).

Dari sekurangya terdapat tiga pembagian lahan secara umum tersebut, daerah pertanian yang biasanya berlereng terjal tersebut terletak pada posisi paling luar, artinya lahan pertanian mengelilingi atau mengitari lahan permukiman sampai pada batas hutan yang ada disekitar desa-desa Tengger.

\section{b. Rumah}

Bagi Suku Tengger, rumah merupakan suatu kebutuhan utama untuk tempat berteduh dari panas dan udara dingin alam pegunungan. Rumah juga berfungsi sebagai sarana sosial (profan) dan sakaral. Bentuk rumah Tengger di Ngadas Kabupaten Malang, Jawa Timur, pada umumnya berbentuk segi empat panjang dengan menggunakan dinding dari kayu yang mudah dapat dicari dari hutan-hutan disekelilingnya. Bentuk atap rumah bergaya atap kampung dengan dasar segi tiga yang ditutupi dengan genteng dan adapula yang menggunakan seng. Tata ruang rumah tinggal dibagi menjadi tiga bagian uatama, yakni:

1. Omah ngarep, berfungsi sebagai tempat untuk menerima tamu dan pertemuanpertemuan tetangga/ kampung.

2. Omah tengah, sebagai ruang keluarga untuk tempat tidur dan kegiatan seharihari, juga tempat untuk mmbuat dan menyimpan perlengkapan upacara adat. Omah tengah terdapat empat tiang utama yang disebut dengan cagak guru/ saka guru . Pada salah satu sudut yang selalu mengarah ke Gunung Semeru/ Bromo/ Tengger terdapat bilik yang disebut dengan bale wetan untuk tempat sesajian dalam upacara tradisional kasodo, karo, dan entas-entas. 
3. Pawon, pawon berfungsi sebagai dapur dan selalu terdapat di bagian belakang rumah, merupakan tempat untuk menaruh, memasak segala keperluan makan sehari-hari. Selain itu powon juga berfungsi sebagai tempat untuk berbincangbincang dengan sahabat dan kerabat dekatnya. Biasanya yang diajak berbincang di pawon adalah mereka yang dianggap sudah dekat/ akrab dengan pemilik rumah.

Pada bagian omah tengah yang terdapat empat buah tiang utama (cagak guru) banyak nilai-nilai simbolis yang sangat menarik untuk diuangkap, karena pada saat mereka hendak memotong hewan kurban, terlebih dahulu harus diikat pada salah satu tiang tersebut. Selain cagak guru juga terdapat bale wetan, bangunan ini selalu mengarah pada ketinggian gunung yang ada disekitarnya. Dengan demikian sebuah rumah selalu memliki bale wetan yang mengarah atau beroreintasi ke Gunung semeru.

\section{Penutup}

Dalam kehidupan umat manusia religi secara universal selalu mendapat perhatian khusus, apalagi bagi komunitas masyarakat yang 'jauh' dari perkembangan peradaban, sebagai contoh adalah masyarakat yang hidup di daerah pegunungan Tengger. Masyarakat ini menjunjung tinggi hal-hal yang berkaitan dengan imanen atau kepercayaan yang diyakini secara turun -temurun. Mengenai latar kepercayaan komunitas ini secara pasti belum diketahui, tetapi pada saat ini masyarakat Tengger yang tinggal di daerah pegunungan (Wong Gunung) telah berkembang agama: Hindhu, Budha, Islam, dan Kristen. Berkembangnya agama-agama tersebut belum banyak mempengaruhi terhadap adat-istiadat dan upacara-upacara tradisional yang mereka lakukan, seperti kasada, karo, dan entas-entas. Upacara adat secara periodik dilakukan setahun sekali oleh seluruh masyarakat Tengger secara bersama-sama baik yang tinggal di pegunungan maupun di bawah (ngare). Kebersamaan sebagai rasa satu saudara (sakturunan) benar-benar tampak dalam kegiatan ritual tersebut tanpa memandang latar agama yang dianut.

Adanya dua pendapat tentang asal mula dan religi orang Tengger di depan dapat di inteprestasikan, bahwa jauh sebelum masa Majapahit dengan agama Hindu dan Budha sebagai agama kerajaan, masyarakat Tengger telah mengenal suatu kepercayaan yakni penyembahan terhadap 'Yang Tertinggi' yang dalam hal ini diwujudkan sebagai obyeknya adalah Gunung Bromo. 'kepercayaan' tersebut boleh dikatakan merupakan kepercayaan asli masyarakat pegunungan Tengger, yang tentunya berbeda dengan konsep-konsep agama Hindu-Budha di istana ibu kota Majapahit. Pengertian yang 'tertinggi' disini bukanlah terbatas pada Gunung Bromo saja, tetapi juga meliputi Gunung Tengger, dan Gunung Semeru yang berada disebelah selatan dan merupakan Gunung tertinggi di Pulau Jawa. Gunung-gunung tinggi inilah yang menjadikan suatu 
pusat orientasi dalam menentukan hubungan antara dunia kini, dunia arwah dan dunia para dewata. Di Desa Ngadas, orientasi batu tegak (menhir) diletakkan dengan cara menghadap arah tenggara, karena Gunung Semeru terletak di sebelah tenggara dari desa Ngadas. Menurut keyakinan mereka, arah timur/ tenggara itulah tempat para dunia arwah dan para penguasa alam serta roh, sehingga dalam pembangunan rumah tinggalpun ada sebuah ruang yang dinamakan dengan nama bale wetan yang selalu terletak/ mengarah ke gunung. Dalam konteks tersebut, unsur-unsur simbolis mewarnai dalam bebepa bangunan dan pandangan hidup orang Tengger.

Rumah dan permukiman sebagai suatu kesatuan yang terletak paling bawah yakni pada dunia nyata yang disikapi oleh seluruh masyarakatnya. Sedangkan tempat-tempat para leluhur atau punden merupakan dunia antara atau mediator untuk mencapai kesempurnaan hidup manusia, sedangkan gunung-gunung tinggi diibaratkan sebagai tempat para 'Yang tertinggi' atau penguasa tertinggi. Pada prinsipnya hidup manusia didunia juga dipengaruhi oleh tiga hal (unsur) tersebut sehingga terdapat keseimbangan secara lahir dan batin.

Unsur-unsur kekunaan budaya materi masyarakat Tengger berupa bale wetan, cagak guru saka guru, punden-punden dan batu tegak (menhir), rupanya memberikan gambaran umum tentang pola permukiman dan rumah masyarakat pegunungan yang masih meneruskan tradisi nenek moyang (leluhur) sampai saat ini. Permukiman sebagai suatu lahan untuk mendirikan rumah selain berfungsi sebagai tempat berlindung juga mengandung nilai-nilai simbolis yang diyakini dan dihormatinya. Tradisi-tradisi yang memiliki unsur pemujaan kepada leluhur dengan wujud mendirikan tempat-tempat untuk upacara ritual pada tata ruang kampung/ permukiman maupun pada rumah tinggal yang selalu berorientasi pada gunung-gunung tinggi di sekitarnya, dapat diasumsikan bahwa masyarakat ini masih melakukan tradisi-tradisi pada masa megalitik.

Masih banyak potensi aspek-aspek budaya yang perlu diungkap secara lengkap melalui pendekatan dan penelitian. Hal yang menarik sebenarnya adalah dengan pendekatan etnoarkeologi. Diharapkan dapat memberikan gambaran tentang masalahmasalah arkeologi utamanya tentang pola-pola permukiman dan letak/ posisi punden/ menhir pada masa megalitik. Sekurangnya dapat mengetahui letak-letak punden/ menhir dengan letak permukimannya itu sendiri. Selama ini kita banyak menemukan menhir sebagai tempat pemujaan, tetapi dimana letak permukimannya itu sendiri masih belum diketahui. Seringkali kita menemukan situs pemujaan berupa menhir, tetapi kita belum dapat mengetahui dimanakah letak dari permukimannya. Apakah letaknya di sekitarnya atau tidak ?. Melalui penelitian yang intensif pada orang Tengger, kiranya dapat sedikit memecahkan masalah permukiman di pegunungan, khususnya di daerah Jawa Timur. 


\section{KEPUSTAKAAN}

Hefner, Robert. W, 1985. Hindu Javanese: Tengger Tradition and Islam. Princeton University Press.

Lelono, Hari, 2001. Unsur-Unsur Kepercayaan Pada Bentuk Permukiman dan Rumah Masyarakat Tengger, Jawa Timur. LPA (Laporan Penelitian Arkeologi). Balai Arkeologi Yogyakarta.

Rangkuti, Nurhadi, 2000. Situs Permukiman Bonang Di Lasem: Tinjauan Khusus Tentang Pola, Struktur dan Proses Keruangannya. Thesis. Program Pasca Sarjana Universitas Gadjah Mada Yogyakarta.

Sedyawati Edi, 1995/1996. Kumpulan Makalah (1993 - 1995), Direktorat Jenderal Kebudayaan Dan Pendidikan.

Sutarto, 2000. Di Balik Mitos Gunung Bromo: Tentang Orang Tengger dan Tradisinya. Dinas Pariwisata Propinsi Jawa Timur.

Wayong, P., 1980/1981. Pola Permukiman Daerah Istimewa Yogyakarta, Depdikbud, Proyek Inventarisasi Dan Dokumentasi Kebudayaan Daerah. 